\title{
The use of genetically modified Roundup Ready soyabean meal and genetically modified MON 810 maize in broiler chicken diets. Part 1. Effects on performance and blood lymphocyte subpopulations
}

\author{
J. Czerwiński1 ${ }^{1,3}$, M. Bogacki ${ }^{2}$, B.M. Jalali², P. Konieczka ${ }^{1}$ and S. Smulikowska ${ }^{1}$ \\ ${ }^{1}$ The Kielanowski Institute of Animal Physiology and Nutrition, Polish Academy of Sciences \\ Instytucka 3, 05-110 Jabłonna, Poland \\ ${ }^{2}$ Institute of Animal Reproduction and Food Research, Polish Academy of Sciences, Department of Gamete and Embryo Biology \\ Tuwima 10, 10-747 Olsztyn, Poland
}

KEY WORDS: broilers, GM soyabean meal, GM maize, performance, T helper lymphocytes, T cytotoxic lymphocytes, flow cytometry
Received: 23 January 2015

Revised: $\quad 28$ May 2015

Accepted: $\quad 15$ June 2015

${ }^{3}$ Corresponding author:

e-mail: j.czerwinski@ifzz.pl

\begin{abstract}
The effects of genetically modified (GM) soyabean meal (SBM) and GM maize (MON 810) on the performance and immunological response of broiler chickens were studied. Eight diets were prepared based on conventional or GM SBM (GTS 40-3-2) combined with non-modified maize cvs. Clarica or PR39 F58 or their isogenic GM counterparts, cvs. Bacilla or PR39 F56. Diets were fed in mash form from day one of age to 192 Ross 308 broiler females, allocated to 8 groups, 24 birds per group. From day 8 to 28 of age, 18 chickens per group were kept in individual cages and performance parameters were measured. After slaughter the shares of T helper and T cytotoxic cells in the blood were determined in 8 birds per group. The feed conversion ratio (FCR) of birds fed GM SBM was better by $3.2 \%$ than in birds fed conventional SBM $(P<0.01)$. The performance of birds fed $\mathrm{GM}$ maize did not differ from those fed conventional maize, but body weight gain was lower and FCR worse by $3.3 \%$ in birds fed diets with Clarica/Bacilla compared with the PR 39 cultivar. The shares of circulating lymphocytes in their entire population averaged $10 \%$ to $17 \%$ and 6.5 to $12.2 \%$ (Thelper and T cytotoxic, respectively) for all groups except the group fed conventional cv. Clarica maize and non-modified SBM ( $31 \%$ and $20.6 \%$, respectively). It may be concluded that the use of GM GTS 40-3-2 soyabean meal and GM MON 810 maize in broiler diets did not negatively affect the feed efficiency and blood lymphocyte subpopulations of broilers.
\end{abstract}

\section{Introduction}

Since the first introduction of large-scale cultivation of genetically modified (GM) crops in 1996, the area cultivated with these crops has continuously increased worldwide, up to 181.5 million hectares in 2014 (ISAAA, 2014). In Europe the feed industry is highly dependent on GM Roundup Ready ${ }^{\mathrm{TM}}$ (RR) soyabean meal (a registered trademark of Monsanto Technology LLC), imported from the USA, Brazil, and Argentina. It is produced mainly from GTS 403-2 soya developed for tolerance to the herbicide glyphosate by the introduction of a gene coding for 5-enolpyruvylshikimate-3-phosphate synthase (EPSPS) from Agrobacterium tumefaciens strain CP4 (CP4 EPSPS protein). It also contains promoter 
$35 \mathrm{~S}$ from the mosaic virus disease of the cauliflower, part of the gene from Petunia hybrida for the transport of EPSPS into the chloroplast, and terminator nos 3 from Agrobacterium tumefaciens (ISAAA, 2014). Soyabean GTS 40-3-2 has been approved for use in food and feeds, but not for cultivation, within the European Union since 2003 (Regulation EC No. 1829/2003). Consumers have been exposed to soyabean GTS 40-3-2 via soyabean oil, while farm animals, including broiler chickens, via solvent-extracted soyabean meal (SBM).

The second most important GM crop is maize, among them maize MON 810 authorized for cultivation (EFSA, 2012a) and for use in foods and animal feeds (EFSA, 2012b) within the European Union. MON 810 maize contains the gene coding for the Cry1A(b) protein, originating from Bacillus thuringiensis (Bt), promoter $35 \mathrm{~S}$ from the mosaic virus disease of the cauliflower, and incorporated maize HSP70 intron. The insert lacks the nos terminator and no vector backbone sequences are present (EFSA, 2012 b). The Cry1A(b) protein is toxic specifically to the European corn borer (Ostrinia nubilalis), a dangerous maize pest under European environmental conditions.

Composition equivalence between first-generation GM and traditional plants has been demonstrated (Flachowsky, 2013), as has been the absence of adverse effects of MON 810 maize and RR soyabean meal in in vivo tests on monogastrics and ruminants (Świątkiewicz et al., 2010; EFSA, 2012b). Nonetheless, genetically modified organism (GMO) feeds are still controversial in many countries. The American Academy of Environmental Medicine suggested that studies on GM feeds should be continued not only on laboratory animals, but also on livestock. The safety assessment should take into account any risk to the consumer of GMO feeds, including, so-called adjuvanticity potential, i.e., the capacity of the newly expressed proteins to increase the immune response in the target animals (Liu et al., 2013).

Einspanier (2013) showed that transgenic DNA and newly expressed proteins are degraded during digestion similarly to native plant DNA and protein. No transfer of recombinant DNA (recDNA) or recombinant proteins (recProteins) from commercialized GM plants has been reliably detected in animal organs or animal products. However, a specific adjuvanticity potential of complete or degraded recProteins cannot be excluded. There are a few reports on negligible effects of MON 810 maize containing the Cry1A(b) protein on the immune response of growing (Walsh et al., 2011) or lactating (Buzoianu et al., 2012) pigs. Scholtz et al. (2010) reported that Bt maize does not impair the immune system of laying Japanese quails, but immune responses in other species of poultry have not been sufficiently documented. Evaluation of the cellular immune response in domestic animals is possible using flow cytometry. $\mathrm{T}$ lymphocytes play a very important role in cell-mediated immunity- $\mathrm{T}$ helper cells $\left(\mathrm{CD}^{+}\right)$produce cytokines and stimulate $\mathrm{B}$ cells, while cytotoxic $\mathrm{T}$ cells $\left(\mathrm{CD} 8^{+}\right)$produce enzymes that induce apoptotic activity and control the death of cells infected by pathogens (Kogut and Klasing, 2009).

The immune system of broilers is sub-optimal in the first four weeks of life. Recent studies by Bednarek et al. (2013) failed to show any significant effect of feeding RR soyabean meal and MON 810 maize on the cellular and humoral immunity of pigs, cattle, or poultry.

The aim of the present study was to evaluate the possible influence of feeding Roundup Ready ${ }^{\mathrm{TM}}$ SBM and MON 810 maize on the performance and cell-mediated immunity of broiler chickens.

\section{Material and methods}

\section{Feedstuffs}

Four cultivars of maize were tested: two cultivars of transgenic (GM) maize MON 810, Bacilla and PR39 F56, and their two non-transgenic counterparts, cvs. Clarica and PR39 F58, respectively, and two commercial solvent-extracted soyabean meals. Seeds of all four maize cultivars were bought from Hi-Bred Northern Europe Sales Division GmbH, European Commission DG Health and Consumers. They have been approved for cultivation within the EU by individual decisions: Clarica (as Clariti CS), approvals No. FR 8197 and IT 345, Bacilla, approvals No. ES 5052 and FR 10858, PR39F58, approvals No. CZ 777, DE 8346, HR 63, and PL 48, PR39F56, approvals no CZ 409 and DE 8346. According to the producer's declaration, cv. Clarica is a non-GM near-isogenic counterpart line for the GM Bacilla cultivar, while PR39F58 is a non-GM near-isogenic counterpart line for the GM PR39F56 cultivar. All four maize cultivars were grown for commercial purposes in 2011 by individual producers in southern Poland. Each cultivar was grown on an area of 40 ha, the distances between fields (buffer zones) were about $1 \mathrm{~km}$. The same herbicides were applied to each field according to the seed producer's recommendations, but no insecticides were applied. According to the farmers' declarations, the yield 
of GM maize was 11 ton $\cdot$ ha $^{-1}$, non-GM maize, 9-10 ton $\cdot \mathrm{ha}^{-1}$. Immediately after harvest, the maize from each field was dried separately in portions of about 30 tons in a grain dryer at $55^{\circ} \mathrm{C}$ for $18 \mathrm{~h}$, cooled, and packed in labelled $50 \mathrm{~kg}$ bags. Maize grain was transported and stored in the labelled bags.

Two commercial solvent-extracted soyabean meals (HIPRO Brasilia) were used, one from a GM batch of Glycine max. L CV. A 5403, line GTS 40-3-2, the second from a non-GM batch (according to the seller's declarations). Representative samples of each maize cultivar and each SBM batch were prepared according to good laboratory practices, analysed in our laboratory, and sent for analysis of genetic modifications. Samples of maize were also analysed for mycotoxins.

Representative subsamples of each of the feeds were analysed in four replications for chemical composition (AOAC, 1990), SBM was also analysed for trypsin inhibitor activity (TIA) according to Kakade et al. (1974) at our laboratory. The presence or absence of genetic modifications was determined by molecular methods according to PN-EN ISO/IEC 17025:2005 at the State Laboratory for Feedstuffs Analysis, National Research Institute of Animal Production (IZ-PIB), Szczecin (Poland). Samples of maize were screened for deoksynivalenol (DON), diacetoksyscirpenol (DAS), nivalenol, HT-2 and $\mathrm{T} 2$, and zearalenon using high-performance liquid chromatography coupled with two mass spectrometers (HPLC-MS/MS) method after filtering on Bond Elut ${ }^{\circledR}$ Mycotoxin columns (Varian, Inc., Palo Alto, CA, USA) at the IZ-PIB laboratory at Balice (Poland). The aflatoxins $B_{1}, B_{2}, G_{1}$, and $G_{2}$ in maize samples were measured by high-performance liquid chromatography with fluorescence detection (HPLCFLD) according to PN-EN 12955:2001, fumonisine $\mathrm{B}_{1}$ and $\mathrm{B}_{2}$ by HPLC-FLD according to PB-43/HPLC ed. III 28.02.2009, ochratoxin A by HPLC-FLD according to PN-EN 14132:2010 at a reference laboratory (Hamilton Poland LTD, Gdynia, Poland).

\section{Experimental diets}

The use of the GM feeds in experimental diets was approved by the Polish Ministry of the Environment. The experimental design consisted of a $2 \times 2 \times 2$ factorial arrangement. Eight experimental diets were formulated (Table 1) to meet or exceed the nutrient requirements for broilers (NRC, 1994). Four diets were based on conventional soyabean meal (S) and: 1. conventional maize cv. Clarica (SC), 2. GM maize cv. Bacilla (SB), 3. conventional maize cv. PR39 F58 (SF58), 4. GM maize cv. PR39 F56 (SF56), and four were based on GM soyabean meal
(SG) and: 5. conventional maize cv. Clarica (SGC), 6. GM maize cv. Bacilla (SGB), 7. conventional maize cv. PR39 F58 (SGF58), 8. GM maize cv. PR39 F56 (SGF56). Diets were analysed for chemical composition (AOAC, 1990) in four replicates.

\section{Experimental details}

All experimental procedures were approved by The Local Animal Care and Use Committee, Warsaw, Poland. A total of 192 one-day-old Ross 308 feather-sexed broiler females were obtained from a local hatchery and placed in 24 battery cages ( 8 birds per cage). The chickens were randomly assigned to 8 experimental treatments, 24 birds each, and fed experimental diets (Table 1) ad libitum in mash form. On day 8, the birds were deprived of feed for $4 \mathrm{~h}(6: 00$ to 10:00 am), weighed and 18 birds per group of a body weight close to the group average were allocated to individual cages. From this point, each bird was treated as a replication and feed intake was individually measured. Room temperature was maintained at $30^{\circ} \mathrm{C}$ for the first 3 days and was gradually reduced thereafter according to standard management practices. A light cycle of $18 \mathrm{~h}$ light and $6 \mathrm{~h}$ darkness (22:00 to 4:00) was maintained throughout the study. On day 29 , the birds were deprived of feed for $4 \mathrm{~h}$ (6:00 to 10:00), feed remnants and birds were weighed, then the same diets were resumed ad libitum until slaughter. Feed intake, body weight gain, and feed conversion ratio for each bird were calculated for the period of 8 to 28 days of age.

\section{Sampling}

Prior to slaughter, the chickens were weighed and anaesthetized by injection of Xylavet (2\% xylazine $\mathrm{v} / \mathrm{v}) /$ Bioketan $(10 \%$ ketamine $\mathrm{w} / \mathrm{v})$ to the peritoneum. In 8 randomly selected chickens per group, the abdominal wall was immediately opened, and $10 \mathrm{ml}$ of blood from the heart was taken and mixed with $0.5 \mathrm{ml}$ of sodium citrate solution (40 g sodium citrate, $8.5 \mathrm{~g} \mathrm{NaCl}$ in $500 \mathrm{ml}$ $\mathrm{H}_{2} \mathrm{O}$ ), and kept at $4^{\circ} \mathrm{C}$ until analysis. The chickens were killed by cervical dislocation, the gonads were examined to verify the sex, the spleen and liver were excised and weighed.

The outliers were not taken for blood and histological analysis. The criterions of qualification as outliers were mainly the presence of a partly unabsorbed yolk sac in the abdominal cavity or distended stomach. Final calculations revealed that males ate, on average, $6.8 \%$ more feed and were $8.8 \%$ heavier than females. The data of males and outliers were excluded from further performance calculations. 
Table 1. Composition of diets

\begin{tabular}{|c|c|c|c|c|c|c|c|c|}
\hline \multirow{2}{*}{ Indices } & \multicolumn{8}{|c|}{ Dietary treatment } \\
\hline & $\mathrm{SC}$ & SB & SF58 & SF56 & SGC & SGB & SGF58 & SGF56 \\
\hline \multirow{2}{*}{\multicolumn{9}{|c|}{$\begin{array}{l}\text { Component, } \mathrm{g} \cdot \mathrm{kg}^{-1} \text { air-DM } \\
\text { soyabean meal }\end{array}$}} \\
\hline & & & & & & & & \\
\hline conventional (S) & 346.55 & 354.2 & 336.3 & 330.0 & - & - & - & - \\
\hline GM (GTS 40-3-2) (SG) & - & - & - & - & 356.2 & 364.0 & 345.6 & 339.5 \\
\hline \multicolumn{9}{|l|}{ maize } \\
\hline conventional cv. Clarica (C) & 616.0 & - & - & - & 606.55 & - & - & - \\
\hline GM (MON 810) cv. Bacilla (B) & - & 608.45 & - & - & - & 598.85 & - & - \\
\hline conventional cv. PR39 F58 (F58) & - & - & 625.95 & - & - & - & 616.85 & - \\
\hline GM (MON 810) cv. PR39 F56 (F56) & - & - & - & 632.25 & - & - & - & 622.75 \\
\hline limestone & 14.3 & 14.3 & 14.3 & 14.2 & 14.2 & 14.2 & 14.2 & 14.3 \\
\hline monocalcium phosphate & 13.2 & 13.1 & 13.3 & 13.4 & 13.1 & 13 & 13.2 & 13.3 \\
\hline $\mathrm{NaCl}$ & 3.0 & 3.0 & 3.0 & 3.0 & 3.0 & 3.0 & 3.0 & 3.0 \\
\hline vitamin-mineral mixture ${ }^{1}$ & 3.1 & 3.1 & 3.1 & 3.1 & 3.1 & 3.1 & 3.1 & 3.1 \\
\hline L-Lys (78\%) & 1.3 & 1.2 & 1.5 & 1.6 & 1.3 & 1.2 & 1.5 & 1.6 \\
\hline DL-Met $(98 \%)$ & 2.3 & 2.4 & 2.3 & 2.2 & 2.3 & 2.4 & 2.3 & 2.2 \\
\hline feed enzyme ${ }^{2}$ & 0.25 & 0.25 & 0.25 & 0.25 & 0.25 & 0.25 & 0.25 & 0.25 \\
\hline \multicolumn{9}{|l|}{ Calculated $^{3}, \mathrm{~g} \cdot \mathrm{kg}^{-1}$ air DM } \\
\hline Lys & 12.0 & 12.1 & 12.0 & 12.0 & 12.0 & 12.1 & 12.0 & 12.0 \\
\hline Met + Cys & 9.0 & 9.1 & 9.1 & 9.0 & 9.0 & 9.0 & 9.1 & 9.0 \\
\hline Thr & 8.0 & 8.0 & 8.0 & 8.0 & 8.0 & 8.0 & 8.0 & 8.0 \\
\hline Trp & 2.5 & 2.5 & 2.5 & 2.5 & 2.5 & 2.5 & 2.5 & 2.5 \\
\hline $\mathrm{Ca}$ & 9.5 & 9.5 & 9.5 & 9.4 & 9.4 & 9.4 & 9.4 & 9.5 \\
\hline$P$ total & 6.5 & 6.5 & 6.5 & 6.5 & 6.5 & 6.5 & 6.5 & 6.5 \\
\hline \multicolumn{9}{|l|}{ Analysed ${ }^{4}$} \\
\hline dry matter, $\mathrm{g} \cdot \mathrm{kg}^{-1}$ & 908 & 904 & 906 & 898 & 910 & 903 & 904 & 900 \\
\hline crude protein, $\mathrm{g} \cdot \mathrm{kg}^{-1} \mathrm{DM}$ & 228 & 227 & 238 & 239 & 237 & 238 & 234 & 236 \\
\hline crude fat, $\mathrm{g} \cdot \mathrm{kg}^{-1} \mathrm{DM}$ & 32 & 32 & 32 & 34 & 32 & 34 & 32 & 32 \\
\hline crude fibre, $\mathrm{g} \cdot \mathrm{kg}^{-1} \mathrm{DM}$ & 38 & 38 & 34 & 32 & 33 & 31 & 30 & 29 \\
\hline
\end{tabular}

${ }_{1}^{1}$ provided the following per $\mathrm{kg}$ diet: $\mathrm{mg}$ : vit. A (retinyl acetate) 3.75 , cholecalciferol 0.069 , vit. E (DL-a-tocopheryl acetate) 50 , thiamine 2 , riboflavin 6 , biotin 0.2 , pyridoxine 4.5 , vit. $B_{12}$ (cyanocobalamin) 0.02 , vit. $\mathrm{K}$ (menadione) 3 , niacin 40 , folic acid 2 , calcium pantothenate 15 , choline 528 , betaine 75, Mg 80, Zn 60, Se 0.25, Co 0.4, Cu 8, Fe 60, I 1; g: Ca 1.415; ${ }^{2}$ Avizyme 1500 (Danisco Cultor) providing per kg of diet: $1000 \mathrm{U}$ subtilisin (protease), $100 \mathrm{U}$ a-amylase, $87 \mathrm{U}$ endo-1,4- $\beta$-xylanase, $37 \mathrm{U}$ endo-1,3 (4)- $\beta$-glucanase and $6 \mathrm{U}$ pectinase, according to manufacturer's declaration; ${ }^{3}$ according to Smulikowska and Rutkowski (2005); ${ }^{4}$ means of 4 replications

\section{Flow cytometry analysis}

The flow cytometry analyses were doneon the day of slaughter at the in-vitro laboratory of the Institute of Animal Reproduction and Food Science, PAS, Olsztyn (Poland). Peripheral blood mononuclear cells (PBMC) from blood samples were isolated using Histopaque (density $=1.077 \mathrm{~g} \cdot \mathrm{ml}^{-1}$; Sigma Aldrich, St. Louis, MO, USA) density gradient centrifugation according to the manufacturer's instructions. The viability of PBMC, as determined by the trypan blue exclusion method, was greater than $98 \%$. The fluorochrome labelled monoclonal antibodies used for this assay were mouse anti-chicken CD45-FITC (clone UM16-6, isotype-IgG2a;), CD4-PE (clone 2-35, isotype-IgG2b), and CD8-PE (clone 11-39, isotype-IgG1) from Abd Serotech (Oxford, UK), and CD3-FITC (clone CT-3, isotype IgG1א) from Southern Biotech (Birmingham, AL, USA) as the directly conjugated antibodies. For one and twocolour staining, $1 \times 10^{6}$ cells in a volume of 100 $\mu \mathrm{l}$ were incubated with fluorescein isothiocyanate (FITC)- or both FITC and phycoerythrin (PE)-conjugated $\mathrm{mAbs}$, for $30 \mathrm{~min}$ on ice, in darkness. After incubation the cells were washed with ice-cold PBS supplemented with 2\% fluorochrome cell sorting (FCS) and resuspended in fluorochrome activated cell sorting (FACS) buffer. The flow cytometry analysis was performed using a BD FACSAria flow cytometer (BD Bioscience, San Jose, CA, USA) and the results were analysed using BD FACSDiva software.

\section{Calculations and statistical analysis}

Feed intake, body weight gain, and feed conversion ratio were calculated for the period from 8 to 28 days, total feed intake was adjusted for feed 
refusal. Spleen and liver weight were expressed per $100 \mathrm{~g}$ of live body weight before slaughter. All data were explored to discard any possible outliers. The distribution analyses were performed using appropriate procedures of SAS software ver. 5.1. (1994-2001), outliers were defined as observations whose distance to location estimate exceeds 3 times the standard deviation. After elimination of males and outliers, the data were analysed as a $2 \times 2 \times 2$ factorial arrangement with three-way ANOVA, using the Statgraphics Plus ${ }^{\circledR}$ ver. 5.1 programme (Statgraphics, 1994-2001). When the ANOVA indicated significant treatment effects, means were separated using Duncan's multiple range tests. In the tables, the results are presented as mean values with pooled standard errors. Differences were considered to be significant at $P \leq 0.05$.

\section{Results}

The quantitative level of RR modification in GTS 40-3-2 SBM used in the experimental diets was $84.91 \% \pm 17.7 \%$. The presence of the $35 \mathrm{~S}$ promotor and nos terminator in conventional soyabean meal was not affirmed (LOQ $<0.05 \%$ ). The quantitative level of genetic modification event MON 810 in the GM maize cvs. Bacilla and PR39 F56 used in the experimental diets was confirmed at the $56.0 \%$ and $50.8 \%$ level, respectively (limit of quantification (LOQ) $<0.1 \%$ ). The presence of genetic modification events NK603, Bt11, Bt176, T25, GA21,TC1507, and MON 88017 was not affirmed in either cvs. Bacilla or PR39 F56 of maize or in their conventional counterparts, cvs. Clarica and PR39 F58 (LOQ $<0.1 \%)$.

The chemical composition of feeds is shown in Table 2. The content of crude protein and crude fibre was higher, whereas that of crude fat, sugars, and ash was lower in conventional than in GM SBM. In both GM maize cultivars, the contents of crude protein and crude fat were higher, but that of crude fibre, lower in comparison with the conventional counterparts. Trypsin inhibitor activity was 5\% higher in GM SBM than in the conventional cultivar.

The concentrations of mycotoxins in the maize used in the experimental diets are shown in Table 3. The concentrations of aflatoxin $B_{1}$, aflatoxin $G_{1}$, and fumonisin $B_{1}$ were below $0.01 \mu \mathrm{g}(\mathrm{ppb}) \cdot \mathrm{kg}^{-1}$, aflatoxin $B_{2}$, aflatoxin $G_{2}$, and fumonisin $B_{1}$ were below $0.05 \mathrm{ppb} \cdot \mathrm{kg}^{-1}$, ochratoxin $\mathrm{A}$ was below $0.25 \mathrm{ppb} \cdot \mathrm{kg}^{-1}$, while the T-2 and HT-2 toxins were not detected in any of the cultivars of conventional or GM maize. Diacetoxyscirpenol was detected in two conventional maize samples and in GM maize cv. Bacilla, but not in PR39 F56. Trichotecenes B and zearalenone were detected in all samples of maize, the deoxynivalenon level was higher in both GM cultivars, while the zearalenone level was higher in GM Bacilla in comparison with conventional cultivars.

No mortality occurred between days 1 and 7 or between days 8 and 28 of life, but 12 males and 6 outliers were revealed after examination of the gonads and intestinal tract immediately after dissection. The birds were kept individually, so it was possible to exclude the data from the male birds and outliers from further statistical performance calculations, but this resulted in a statistically significant difference between some groups in initial body weight (Table 4).

As shown in Table 4, in the period from day 8 to 28 of age, the use of GM SBM in diets affected neither feed intake, nor body weight gain, but improved, however, the feed-to-gain ratio by about $2.7 \%(P<0.01)$ in comparison with broilers receiving the diet with conventional soyabean meal.

Table 2. Chemical composition of evaluated feeds, $\mathrm{g} \cdot \mathrm{kg}^{-1}$ dry matter

\begin{tabular}{|c|c|c|c|c|c|c|}
\hline \multirow[b]{2}{*}{ Component $^{1}$} & \multicolumn{2}{|c|}{ Soyabean meal } & \multicolumn{4}{|l|}{ Maize } \\
\hline & conventional & GM (MON 40-3-2) & $\begin{array}{l}\text { conventional } \\
\text { cv. Clarica }\end{array}$ & cv. PR39 F58 & $\begin{array}{l}\text { GM (MON 810) } \\
\text { cv. Bacilla }\end{array}$ & cv. PR39 F56 \\
\hline Dry matter, $\mathrm{g} \cdot \mathrm{kg}^{-1}$ & 877.0 & 884.0 & 889.0 & 880.0 & 879.0 & 881.0 \\
\hline Crude protein & 535.6 & 519.5 & 90.7 & 97.6 & 85.7 & 102.6 \\
\hline Crude fat & 10.8 & 16.5 & 44.9 & 48.6 & 44.9 & 47.9 \\
\hline Crude fibre & 47.4 & 36.4 & 28.9 & 22.7 & 27.5 & 21.5 \\
\hline ADF & 125.4 & 81.3 & 41.4 & 35.7 & 39.6 & 39.5 \\
\hline NDF & 178.2 & 139.4 & 186.8 & 192.9 & 168.3 & 155.8 \\
\hline ADL & 12.9 & 13.5 & 9.5 & 8.0 & 11.0 & 9.7 \\
\hline Sugars & 140.1 & 166.2 & 72.4 & 64.7 & 58.4 & 91.3 \\
\hline Starch & 0.0 & 0.0 & 676.4 & 697.8 & 725.9 & 696.3 \\
\hline Ash & 62.5 & 65.2 & 13.5 & 16.0 & 12.7 & 13.6 \\
\hline$\underline{\mathrm{TIA}}, \mathrm{mg} \cdot \mathrm{g}^{-1}$ & 2.76 & 2.89 & - & - & - & - \\
\hline
\end{tabular}

${ }^{1}$ means of 4 replications; TIA - mg pure trypsin inhibited per gram sample 
Table 3. The concentration of mycotoxins in conventional and GM maize used in experimental diets

\begin{tabular}{|c|c|c|c|c|c|}
\hline \multirow{3}{*}{ Mycotoxin } & \multicolumn{4}{|l|}{ Maize } & \multirow{3}{*}{$\begin{array}{l}\text { Guidance value, } \\
\mu \mathrm{g} \cdot \mathrm{kg}^{-1}\end{array}$} \\
\hline & \multicolumn{2}{|c|}{ conventional } & \multicolumn{2}{|c|}{ GM (MON 810) } & \\
\hline & cv. Clarica & cV. PR39 F58 & cv. Bacilla & cv. PR39 F56 & \\
\hline \multicolumn{6}{|l|}{ Aflatoxins, $\mu \mathrm{g} \cdot \mathrm{kg}^{-1}$} \\
\hline $\mathrm{B}_{1}$ & $<0.10$ & $<0.10$ & $<0.10$ & $<0.10$ & $10^{1}$ \\
\hline $\mathrm{B}_{2}$ & $<0.05$ & $<0.05$ & $<0.05$ & $<0.05$ & \\
\hline $\mathrm{G}_{1}$ & $<0.10$ & $<0.10$ & $<0.10$ & $<0.10$ & \\
\hline $\mathrm{G}_{2}$ & $<0.05$ & $<0.05$ & $<0.05$ & $<0.05$ & \\
\hline Ochratoxin $\mathrm{A}, \mu \mathrm{g} \cdot \mathrm{kg}^{-1}$ & $<0.25$ & $<0.25$ & $<0.25$ & $<0.25$ & $250^{2}$ \\
\hline Fumonisins, $\mathrm{mg} \cdot \mathrm{kg}^{-1}$ & & & & & $60000\left(B_{1}+B_{2}\right)^{2}$ \\
\hline $\mathrm{B}_{1}$ & $<0.10$ & $<0.10$ & $<0.10$ & $<0.10$ & \\
\hline $\mathrm{B}_{2}$ & $<0.04$ & $<0.04$ & $<0.04$ & $<0.04$ & \\
\hline \multicolumn{6}{|l|}{ Trichothecenes A, $\mu \mathrm{g} \cdot \mathrm{kg}^{-1}$} \\
\hline diacetoxyscirpenol (DAS) & 4.47 & 5.63 & $<1.00$ & ND & \\
\hline T-2 toxin & ND & ND & ND & ND & \\
\hline HT-2 toxin & ND & ND & ND & ND & \\
\hline \multicolumn{6}{|l|}{ Trichothecenes B, $\mu \mathrm{g} \cdot \mathrm{kg}^{-1}$} \\
\hline deoxynivalenol (DON) & 35.90 & 75.70 & 296.00 & 217.00 & $8000^{2}$ \\
\hline nivalenol & 89.20 & 32.20 & $<3.00$ & 3.75 & \\
\hline Zearalenone (ZEA), $\mu \mathrm{g} \cdot \mathrm{kg}^{-1}$ & 1.50 & 4.17 & 28.90 & 2.21 & $2000^{2}$ \\
\hline
\end{tabular}

${ }^{1}$ according to Directive 2002/32/EC; ${ }^{2}$ according to Commission Recommendation (OJ, 2006); ND - not detected

Table 4. Effects of feeding GM or conventional soyabean meal and two cvs. of maize on performance (8-28 d of life) and spleen and liver weight of broilers

\begin{tabular}{|c|c|c|c|c|c|c|c|}
\hline Indices & $\mathrm{n}^{1}$ & $\begin{array}{l}\text { Feed } \\
\text { intake, } \\
\mathrm{g}\end{array}$ & $\begin{array}{l}\text { Initial } \\
\mathrm{BW}^{2} \text {, } \\
\mathrm{g}\end{array}$ & $\begin{array}{l}\mathrm{BWG}^{3}, \\
\mathrm{~g}\end{array}$ & $\begin{array}{l}\text { Feed/gain ratio, } \\
\mathrm{g} \cdot \mathrm{g}^{-1}\end{array}$ & $\begin{array}{l}\text { Spleen } \\
\text { g/100 g }\end{array}$ & $\begin{array}{l}\text { Liver }^{4} \\
\mathrm{~g} / 100 \mathrm{~g}\end{array}$ \\
\hline \multicolumn{8}{|l|}{ Dietary treatment } \\
\hline SC & 17 & $1780^{\circ}$ & $152^{\mathrm{ab}}$ & $1118^{\text {bcd }}$ & $1.59^{\mathrm{cd}}$ & 0.085 & 3.40 \\
\hline SB & 16 & $1675^{\mathrm{ab}}$ & $144^{\mathrm{a}}$ & $1030^{a}$ & $1.63^{d}$ & 0.112 & 3.08 \\
\hline SF58 & 14 & $1764^{\text {bc }}$ & $157^{b}$ & $1134^{\text {bcd }}$ & $1.56^{\mathrm{bc}}$ & 0.094 & 3.24 \\
\hline SF56 & 17 & $1691^{\mathrm{ab}}$ & $149^{a b}$ & $1118^{\text {bcd }}$ & $1.52^{\mathrm{a}}$ & 0.094 & 2.98 \\
\hline SGC & 15 & $1669^{a b}$ & $151^{a b}$ & $1071^{a b}$ & $1.56^{\mathrm{bc}}$ & 0.089 & 3.04 \\
\hline SGB & 14 & $1648^{a}$ & $145^{\mathrm{a}}$ & $1080^{\mathrm{abc}}$ & $1.53^{\mathrm{ab}}$ & 0.102 & 3.18 \\
\hline SGF58 & 16 & $1742^{\mathrm{bc}}$ & $151^{\mathrm{ab}}$ & $1153^{d}$ & $1.52^{\mathrm{a}}$ & 0.091 & 3.17 \\
\hline SGF56 & 17 & $1722^{\mathrm{abc}}$ & $148^{\mathrm{a}}$ & $1143^{c d}$ & $1.51^{\mathrm{a}}$ & 0.100 & 3.04 \\
\hline pooled SEM & & 33.0 & 3.1 & 23.8 & 0.02 & 0.008 & 0.12 \\
\hline \multicolumn{8}{|l|}{ Main effect } \\
\hline \multicolumn{8}{|l|}{ soyabean meal (S) } \\
\hline conventional & 64 & 1727 & 151 & 1100 & $1.58^{\mathrm{B}}$ & 0.096 & 3.17 \\
\hline GM (GTS 40-3-2) & 62 & 1695 & 149 & 1112 & $1.53^{\mathrm{A}}$ & 0.096 & 3.11 \\
\hline pooled SEM & & 16.5 & 1.6 & 11.9 & 0.01 & 0.004 & 0.06 \\
\hline \multicolumn{8}{|l|}{ maize (M) } \\
\hline conventional & 62 & $1739^{b}$ & $153^{\mathrm{B}}$ & 1119 & 1.56 & $0.090^{\mathrm{a}}$ & 3.21 \\
\hline GM (MON 810) & 64 & $1684^{a}$ & $146^{A}$ & 1093 & 1.55 & $0.102^{b}$ & 3.07 \\
\hline pooled SEM & & 16.5 & 1.6 & 11.9 & 0.01 & 0.004 & 0.06 \\
\hline \multicolumn{8}{|l|}{ maize cvs. (MC) } \\
\hline Clarica/Bacilla & 62 & 1693 & 148 & $1075^{A}$ & $1.58^{\mathrm{B}}$ & 0.097 & 3.18 \\
\hline PR39 & 64 & 1730 & 151 & $1137^{\mathrm{B}}$ & $1.52^{\mathrm{A}}$ & 0.095 & 3.11 \\
\hline pooled SEM & & 16.5 & 1.6 & 11.9 & 0.01 & 0.004 & 0.06 \\
\hline \multicolumn{8}{|l|}{ Interaction } \\
\hline$S \times M$ & & Ns & Ns & Ns & Ns & Ns & Ns \\
\hline$S \times M C$ & & Ns & Ns & Ns & 0.004 & Ns & Ns \\
\hline$M \times M C$ & & Ns & Ns & Ns & Ns & Ns & Ns \\
\hline$S \times M \times M C$ & & Ns & Ns & Ns & 0.001 & Ns & Ns \\
\hline
\end{tabular}

${ }^{1}$ number of birds taken to statistical performance analysis, after males and outliers elimination; ${ }^{2} \mathrm{BW}$ - body weight; ${ }^{3} \mathrm{BWG}$ - body weight gain; ${ }^{4}$ means of 8 chickens, for three-way analysis, $n=32$; ${ }^{a-d, A, B}$ within main effects means in columns with different superscripts differ significantly at: a,b $P<0.05, A, B P<0.01$, Ns - not significant 
Birds receiving diets with GM maize consumed $4.1 \%$ less feed $(P<0.01)$ and had a 3.6\% lower body weight $(P<0.05)$, but the feed-to-gain ratio was not affected in comparison with birds fed conventional maize. The maize cultivar did not affect feed intake, but birds fed with maize cv. PR39 were heavier and had a better feed-to-gain ratio in comparison with the groups fed maize cv. Clarica/Bacilla $(P<0.01)$. The use of GM soyabean meal in diets with cv. Clarica/Bacilla maize improved the feed-to-gain ratio more than in diets with cv. PR39 maize, which gave interactions between the influence of modification of soyabean meal and maize cultivar $(P<0.004)$ and between the influence of all three treatments $(P<0.001)$ on the feed-to-gain ratio. Neither GM soyabean meal and maize nor maize cultivar

Table 5. Effects of feeding conventional (S) or GM (SG) soyabean meal and conventional maize (Clarica and PR39F58) or their GM counterparts (Bacilla and PR39F56) on T helper and T cytotoxic cells in blood of broilers

\begin{tabular}{|c|c|c|c|}
\hline \multirow{2}{*}{ Indices } & Thelper cells & T cytotoxic cells & \multirow{2}{*}{$\begin{array}{l}\text { T helper/ } \\
\text { T cytotoxic } \\
\text { cells ratio }\end{array}$} \\
\hline & \multicolumn{2}{|c|}{ \% total lymphocytes } & \\
\hline \multicolumn{4}{|l|}{ Dietary treatment ${ }^{1}$} \\
\hline SC & $31.12^{d}$ & $20.64^{c}$ & $1.52^{\mathrm{ab}}$ \\
\hline SB & $11.30^{\mathrm{ab}}$ & $9.69^{\mathrm{ab}}$ & $1.18^{\mathrm{a}}$ \\
\hline SF58 & $15.39^{b c}$ & $12.22^{b}$ & $1.35^{\mathrm{ab}}$ \\
\hline SF56 & $12.63^{\mathrm{abc}}$ & $9.43^{\mathrm{ab}}$ & $1.38^{\mathrm{ab}}$ \\
\hline SGC & $16.96^{c}$ & $6.96^{\mathrm{a}}$ & $2.64^{c}$ \\
\hline SGB & $14.27^{\mathrm{abc}}$ & $8.10^{\mathrm{a}}$ & $1.89^{\mathrm{b}}$ \\
\hline SGF58 & $12.82^{\mathrm{abc}}$ & $8.02^{\mathrm{a}}$ & $1.66^{\mathrm{ab}}$ \\
\hline SGF56 & $10.14^{a}$ & $6.54^{a}$ & $1.64^{\mathrm{ab}}$ \\
\hline pooled SEM & 1.66 & 1.23 & 1.55 \\
\hline \multicolumn{4}{|l|}{$\begin{array}{l}\text { Main effects }{ }^{2} \\
\text { soyabean meal (S) }\end{array}$} \\
\hline conventional & $17.61^{\mathrm{B}}$ & $13.00^{\mathrm{B}}$ & $1.35^{\mathrm{A}}$ \\
\hline GM (GTS 40-3-2) & $13.55^{\mathrm{A}}$ & $7.40^{\mathrm{A}}$ & $1.96^{\mathrm{B}}$ \\
\hline pooled SEM & 0.83 & 0.61 & 0.10 \\
\hline \multicolumn{4}{|l|}{ maize $(\mathrm{M})$} \\
\hline conventional & $19.07^{\mathrm{B}}$ & $11.96^{\mathrm{B}}$ & 1.79 \\
\hline GM (MON 810) & $12.08^{A}$ & $8.44^{\mathrm{A}}$ & 1.52 \\
\hline pooled SEM & 0.83 & 0.61 & 0.10 \\
\hline \multicolumn{4}{|l|}{ maize cvs. (MC) } \\
\hline Clarica/Bacilla & $18.41^{B}$ & $11.35^{b}$ & $1.81^{b}$ \\
\hline PR39 & $12.74^{\mathrm{A}}$ & $9.05^{\mathrm{a}}$ & $1.51^{\mathrm{a}}$ \\
\hline pooled SEM & 0.83 & 0.61 & 0.10 \\
\hline \multicolumn{4}{|l|}{ Interactions $(P)$} \\
\hline$S \times M$ & 0.0006 & 0.0003 & Ns \\
\hline$S \times M C$ & Ns & 0.0229 & 0.0264 \\
\hline $\mathrm{M} \times \mathrm{MC}$ & 0.0006 & Ns & 0.0489 \\
\hline$S \times M \times M C$ & 0.0007 & 0.0032 & Ns \\
\hline
\end{tabular}

${ }^{1}$ means of 8 chickens, ${ }^{2}$ for main effects $n=32$; a,b,A,B within dietary treatments and main effects means in columns with different superscripts differ significantly at: ${ }^{a, b} P<0.05,{ }^{A, B} P<0.01$; Ns - not significant affected liver weight. Spleen weight was about 13\% greater $(P<0.05)$ in birds given GM feeds in comparison with conventional maize, but it was not affected by other dietary treatments (Table 4).

The effects of dietary treatments on the proportions of $\mathrm{T}$ helper and $\mathrm{T}$ cytotoxic cells within the entire population of lymphocytes are shown in Table 5 . The percentage shares of $\mathrm{T}$ helper and $\mathrm{T}$ cytotoxic cells were distinctly higher in birds fed the SC diet containing conventional soyabean meal and unmodified maize cv. Clarica, than in birds fed the SB diet (conventional soyabean meal and GM maize cv. Bacilla), the difference was much lower in chickens fed diets with conventional SBM and unmodified or GM maize (cv. PR39). Within groups fed GM soyabean meal and Clarica/Bacilla maize (SGC and SGB), the percentage shares of $\mathrm{T}$ helper cells differed less than in groups fed cv. PR39 maize, but the $\mathrm{T}$ helper to $\mathrm{T}$ cytotoxic cell ratios were higher in both groups than in the remaining groups. This is why all of the treatment effects, as well as interaction effects, were highly significant $(P<0.01)$. Birds fed with maize cv. Clarica/Bacilla had higher Thelper to $T$ cytotoxic cell ratios in comparison with the groups fed maize cv. PR39 $(P<0.05)$ (Table 5). The differences observed in the Clarica/Bacilla pair of maize were not observed for the PR39 F58/PR39 F56 pair and, therefore, were less likely to be related to the GM trait.

\section{Discussion}

The nutrient contents in the SBM and maize used in this experiment were within the limits for both feeds published in tables (NRC, 1994; Smulikowska and Rutkowski, 2005). The trypsin inhibitor activity was $5 \%$ higher in GM SBM than in the conventional one, but both values were within the limits accepted for toasted soyabean meals (Huisman and Jansman, 1991).

In GM maize of both cultivars, the concentration of aflatoxins, ochratoxin A, fumonisins, T-2 toxin, and HT-2 toxin did not differ and were below detection levels. The concentrations of diacetoxyscirpenol were about $5 \mu \mathrm{g} \cdot \mathrm{kg}^{-1}$ in conventional maize cultivars, while in the respective GM cultivars, they were less than $1 \mu \mathrm{g} \cdot \mathrm{kg}^{-1}$ or under the detection level. The concentrations of deoxynivalenol were 36 and $76 . \mu \mathrm{g} \cdot \mathrm{kg}^{-1}$ in conventional maize cultivars, while in its GM counterparts, they were 8-fold and 3-fold higher, respectively, while the concentration of nivalenol was 30 and 8 times lower in the GM counterparts. Several investiga- 
tors have reported that the incidence of mycotoxin contamination was reduced in Bt maize (Quarantelli et al., 2007). In our study, the concentration of zearalenone was 20 times higher in GM cv. Bacilla than in its unmodified Clarica counterpart. However, even the highest concentrations of the detected mycotoxins were from 27 times (deoxynivalenol) to 70 times (zearalenone) lower than the guidance values recommended in the EU for animal feeds (Commission Recommendation, 2006/576/EC).

In the nutritional assessment procedure for testing GM feeds in animal trials, it is desirable to obtain the highest concentration possible of the GM feed in the diet (EFSA, 2008). Accordingly, in the present study the main components of the diets were maize and soyabean meal, but these diets cannot be pelleted and were fed in mash form. Broilers fed mash diets eat less and, therefore, have relatively lower body weights than broilers fed pelleted diets. The use of GM soyabean meal in broiler diets had no adverse effect on either feed intake or body weight gain, but improved the feed-to-gain ratio in comparison with non-GM soyabean meal. Similar findings have been reported by many authors (e.g., Kan and Hartnell, 2004; Świątkiewicz et al., 2010). In contrast, in the current study the feed intake and body weight gain of broilers fed GM maize was lower in comparison with birds fed conventional maize, but the feed-to-gain ratio was not influenced. Body weight gain and the feed-to-gain ratio in birds fed the maize PR39 (F58 and F 56) cultivars were better than in birds fed the Clarica/Bacilla cultivars. It should be emphasized that because each bird was kept individually, and thus was treated as a replication, feed intake and FCR were precisely measured and the elimination of males did not detrimentally affect group performance results.

In many studies involving broilers, no evidence has been found for adverse effects on performance of different events of GM herbicide-tolerant or insectresistance maize. Taylor et al. (2003), in two 42-day experiments on broilers (Ross $\times$ Ross 508), showed that feed intake, final body weight, and feed conversion ratio were not affected by diets containing glyphosate-tolerant maize event NK603 (Roundup Ready) and insect-protected maize event MON 810 $\times$ glyphosate-tolerant maize event NK603 (YieldGard $\times$ Roundup Ready) in comparison with their respective non-transgenic counterparts and with a commercial reference maize. Brake et al. (2003) in a 42-day feeding study on broilers, showed that diets containing Syngenta Seeds NK Brand Bacillus thuringiensis $(B t)$ maize hybrids sprayed or not sprayed with Liberty brand herbicide (glyphosate) had no adverse effects on the performance of male and female birds in comparison with their respective non-transgenic counterparts. However, all three GM maize hybrids did adversely affect the final body weight of birds and feed conversion ratio in comparison with commercial reference maize.

The immune system of poultry is a complex, multi-factorial entity, composed of many primary and secondary lymphoid tissues (Glick, 2000). Immune functions are affected by many factors, among others by bird age, genetic potential for growth, environmental conditions, and stress, but also by dietary factors. In the current study, the use of GM soyabean meal and the cultivar of maize had no influence on the weight of the spleen, which is one of the major lymphatic organs involved in birds' immune responses. However, in chickens fed GM maize (both the group with cv. Bacilla and the group fed PR39F58 and GM soyabean meal), the average spleen weight was larger, the difference between GM and conventional maize was significant. Contrary to our results, ̌̌ehout et al. (2009) showed that maize MON 810 had no influence on the spleen weight of Ross 308 broilers, but the content of maize in their experimental diets was lower (about 30\%) than in our study.

$\mathrm{T}$ lymphocytes play a very important role in the cellular immune response (Kogut and Klasing, 2009). In chickens a wide range in percentages of $\mathrm{CD}$ markers has been reported, with a lower percentage of CD8+ cytotoxic cells as compared with CD4+ helper cells in peripheral blood (Fair et al., 2008). In the present study, the level of GM feeds in the diets was high, but all lymphocyte proportions in GM-fed birds were within the range of physiological values found by other authors (Fair et al., 2008; Bednarek et al., 2013). However, birds fed maize cv. Clarica/Bacilla had higher T helper-to-T cytotoxic cell ratios in comparison with the groups fed maize cv. PR39. The percentage shares of $T$ helpers was approximately two-fold higher, and that of $\mathrm{T}$ cytotoxic cells, though in the physiological range, was distinctly higher in birds fed the diet containing conventional SBM and unmodified maize cv. Clarica, than in all of the other groups (Table 5). Bohn et al. (2014) reported that conventional and genetically modified plants can contain different concentrations of residues of pesticides used for soyabean protection or insecticides used for maize protection. We assume that the relatively higher percentages of $\mathrm{T}$ cells in the birds fed unmodified maize cv. Clarica may be an inflammatory reaction to the presence of insecticides in the diet. Unfortunately, the concentration of pesticides in different diets was not 
measured in this study. That differences observed in the Clarica/Bacilla pair of maize were not observed for the PR39 F58/F56 pair and, therefore, were less likely to be related to the GM trait.

Despite the very high level of GM feeds in the diets used in the present study, our results corroborate reports on the negligible effects of MON 810 maize containing the Cry1 A(b) protein on the immune response of growing (Walsh et al., 2011) or lactating (Buzoianu et al., 2012) pigs. Scholtz et al. (2010) reported that GM Bacillus thuringiensis-maize does not impair the immune system of laying Japanese quails. Bednarek et al. (2013) reported that the use of RR soyabean meal in dietary concentrations of about $14 \%$ to $18 \%$, and MON 810 maize at about $10 \%$ to $13 \%$ had no influence on different blood lymphocyte subpopulations in broiler chickens and laying hens. It seems, however, that components not identified in this study present in conventional maize may activate the immune system of birds. In the second part of our study, the influence of genetically modified soyabean meal and maize on the health status of the gastrointestinal tract of broiler chickens will be described.

\section{Conclusions}

It may be concluded, based on the results of the present study, that the use of genetically modified Roundup Ready soyabean meal (GTS 40-3-2) and/ or genetically modified maize (MON 810) in broiler chicken diets did not negatively affect the feed efficiency and blood lymphocyte subpopulations of the birds.

\section{Acknowledgements}

Financial support was provided by the Polish National Science Centre - Grant No. N N311 517540 .

\section{References}

AOAC, 1990. Association of Official Analytical Chemists, Official Methods of Analysis. $15^{\text {th }}$ Edition. Washington, DC

Bednarek D., Dudek K., Kwiatek K., Świątkiewicz M., Światkiewicz S., Strzetelski J., 2013. Effect of a diet composed on genetically modified feed components on the selected immune parameters in pigs, cattle, and poultry. Bull. Vet. Inst. Pulawy, 57, 209-217

Bohn T., Cuhra M., Traavik T., Sanden M., Fagan J., Primicerio R., 2014. Compositional differences in soybeans on the market: Glyphosate accumulates in Roundup Ready GM soybeans. Food Chem. 153, 207-215
Brake J., Faust M.A., Stein J., 2003. Evaluation of transgenic event Bt11 hybrid corn in broiler chickens. Poultry Sci. 82, 551-559

Buzoianu S.G., Walsh M.C., Rea M.C. et al., 2012. Effects of feeding Bt maize to sows during gestation and lactation on maternal and offspring immunity and fate of transgenic material. PLOS ONE, 7(10):e47851

Commission Recommendation 2006/576/EC of 17 August on the presence of deoxynivalenol, zearalenone, ochratoxin A, T-2 and $\mathrm{HT}-2$ fumonisins in products intended for animal feeding. Official Journal of the European Union - OJEU ser. L, 229, 23.8.2006, pp. 7-9

EFSA GMO Panel, 2008. Safety and nutritional assessment of GM plants and derived food and feed: The role of animal feeding trials - Review. Food Chem. Toxicol. 46, S2-S70

EFSA, 2012a. Scientific opinion supplementing the conclusions of the environmental risk assessment and risk management recommendations for the cultivation of the genetically modified insect resistant maize Bt11 and MON 810. EFSA J. 3016, 1-32

EFSA, 2012b. Scientific opinion updating the risk assessment conclusions and risk management recommendations on the genetically modified insect resistant maize MON 810. EFSA J. 3017, $1-98$

Einspanier R., 2013. The fate of transgenic DNA and newly expressed proteins. In: G. Flachowsky (Editor). Animal Nutrition with Transgenic Plants. CABI Biotechnology Series, pp. 130-139

Fair J.M., Taylor-McCabe K.J., Shou Y., Marrone B.L., 2008. Immunophenotyping of chicken peripheral blood lymphocyte subpopulations: Individual variability and repeatability. Vet. Immunol. Immunopathol. 125, 268-273

Flachowsky G., 2013. Feeding studies with first-generation GM plants (input traits) with food-producing animals. In: G. Flachowsky (Editor). Animal Nutrition with Transgenic Plants. CABI Biotechnology Series, pp. 72-93

Glick B., 2000. Immunophysiology. In: G. Whittow (Editor). Sturkie's Avian Physiology, $5^{\text {th }}$ Edition. Academic Press, pp. 657-670

Huisman J., Jansman A.J.M., 1991. Dietary effects and some analytical aspects of antinutritional factors in peas (Pisum sativum), common beans (Phaseolus vulgaris) and soyabeans (Glycine max L.) in monogastric farm animals. A literature review. Nutr. Abstr. Rev., Ser. B 61, 901-921

ISAAA, 2014. Global status of commercialized biotech/GM crops: 2014. International Service for the Acquisition of Agri-biotech Applications in Brief, No. 49-2014. ISAAA: Ithaca, NY. http:// www.isaaa.org/resources/publications/briefs/49/executivesummaryl

Kakade M.C., Rackis J.J., McGhee J.E., Puski G., 1974. Determination of trypsin inhibitor activity of soy products: collaborative analysis of an improved procedure. Cereal Chem. 51, 376-382

Kan C.A., Hartnell G.F., 2004. Evaluation of broiler performance when fed insect-protected, control, or commercial varieties of dehulled soyabean meal. Poultry Sci. 83, 2029-2038

Kogut M.H., Klasing K., 2009. An immunologist's perspective on nutrition, immunity, and infectious diseases: Introduction and overview. J. Appl. Poultry Res. 18, 103-110

Liu Y., Christodoulidou A., Dumont A.F., Germini A., Paoletti C., 2013. Guidance documents for nutritional and safety assessment of feeds from GM plants. In: G. Flachowsky (Editor). Animal Nutrition with Transgenic Plants. CABI Biotechnology Series, pp. $30-49$

NRC, 1994. Nutrients Requirements of Poultry. $9^{\text {th }}$ Edition. National Academic Press, Washington, DC

Quarantelli A., Veroli E., Romanelli S., Renzi M., Righi F., 2007. GMO utilization in animal nutrition. Ann. Fac. Med. Vet. di Parma, $27,211-228$ 
Řehout V., Kadlec J., Čítek J., Hradecká E., Hanusová I., Hosnedlová B., Lád F., 2009. The influence of genetically modified Bt maize MON 810 in feed mixtures on slaughter, haematological and biochemical indices of broiler chickens. J. Anim. Feed Sci. 18, 490-498

Scholtz N.D., Halle I., Dänicke S., Hartmann G., Zur B., Sauerwein H., 2010. Effects of an active immunization on the immune response of laying Japanese quail (Coturnix coturnix japonica) fed with or without genetically modified Bacillus thuringiensismaize. Poultry Sci. $89,1122-1128$

Statgraphics $®$ ver. 5.1., 1994-2001. Statistical Graphic System by Statistical Graphic Corp

Smulikowska S., Rutkowski A. (Editors), 2005. Recommended Allowances and Nutritive Value of Feedstuffs - Poultry Feeding Standards (in Polish). $4^{\text {th }}$ Edition. The Kielanowski Institute of Animal Physiology and Nutrition, PAS, Jabłonna (Poland)
Świątkiewicz S., Świątkiewicz M., Koreleski J., Kwiatek K., 2010. Nutritional efficiency of genetically-modified insect resistant corn (MON810) and glyphosate-tolerant soyabean meal (Roundup Ready) for broilers. Bull. Vet. Inst. Pulawy 54, 43-48

Taylor M.L., Hartnell G.F., Riordan S.G., Nemeth M.A., Karunanandaa K., George B., Astwood J.D., 2003. Comparison of broiler performance when fed diets containing grain from Roundup Ready (NK603), YieldGard x Roundup Ready (MON810 x NK603), non-transgenic control, or commercial corn. Poultry Sci. 82, 443-453

Walsh M.C., Buzoianu S.G., Gardiner G.E. et al., 2011. Fate of transgenic DNA from orally administered BT MON810 maize and effects on immune response and growth in pigs. PLoS One 6 (11):e27177 